\title{
The Important of Training and its Impact on the Performance of Employees in Banking Sectors (Abu Dhabi - UAE) to Rise Efficiency
}

\author{
Burhan Mahmoud Awad Alomari ${ }^{1}$, AlaEldin Mohammad Hasan Awawdeh ${ }^{1} \&$ Main Naser Alolayyan ${ }^{1}$ \\ ${ }^{1}$ Emirate College of Technology (ECT), Human Resource Management Department, Emirate College of \\ Technology, Abu Dhabi, UAE \\ Correspondence: Burhan Mahmoud AwadAlomari, Human Resource Management Department, Emirate College \\ of Technology, Abu Dhabi, UAE. Tel: 97-150-474-3122. E-mail: burhan.alomari@ect.ac.ae; \\ alaeldin.awawdeh@ect.ac.ae; main.naser@ect.ac.ae; dr.alolayyan@rocketmail.com
}

Received: July 18, 2017

doi:10.5539/mas.v11n9p138
Accepted: July 26, 2017

Online Published: August 29, 2017

URL: https://doi.org/10.5539/mas.v11n9p138

\begin{abstract}
The study aims at measuring the impact of human resource management practices on creativity and innovation with the presence of competencies as an intermediary variable. The study highlights the importance of human resource management practices for UAE banks and explores the role of human resource management practices in enhancing the creativity and innovation of employees. To achieve this goal, six UAE banks were selected as a study area. A questionnaire was designed and distributed to a random sample of 150 respondents. The analytical, descriptive method was used for analysis. Data analysis and testing were carried out using SPSS.

Some of the most important outcomes of this study are: Human resource management practices such as compensation and benefits, employment, empowerment and human resources planning have a positive impact on innovation. Compensation, benefits, employment, training and development, also have a positive effect on creativity. Human resource management practices have a positive impact on training. The study recommends that giving the UAE banks the priority of human resource management practices is of great importance in their dimensions according to the scale of human resource management practices that are interested in achieving innovation and creativity for employees within the banks. The further studies are suggested related to human resources management practices and creativity and innovation because of their impact on achieving competitive advantage.
\end{abstract}

Keywords: performance management, employee engagement, talent management, personnel, and working conditions, banking sectors

\section{Introduction}

\subsection{The Study}

The subject of the training of human resources and private managers and their development is important issue for any organization, especially banks, where the human element is the main engine of the resources of these organizations. Especially, when we talk about the quality of the skills and abilities of knowledge that commensurate with the nature of the work of the organization in which it operates, and training with an effective impact on the profitability of the human element through the process of administrative efforts. It is necessary to maintain efficient work of the high strength to any level of manager and those who work under his/her supervision in terms of raising the level of skills and help to instill confidence in the hearts of workers and improve the quality of work.

Any organizations that do not pay attention to the subject of training or where there is no continuous improvement through training programs will find themselves in trouble as a result of the many changes that occur in the surrounding. Every change requires the organization re-examination composition skills, knowledge and abilities of its human resources to fit with the new environmental requirements of all private commercial banks wherever the environment is altered.

A senior leader in commercial banks must be effective and the effectiveness can be measured by the performance of the leaders and managers. Therefore, the ability to align and motivate teams to drive business results is crucial to their success. The Strategic Leaders of Training Program, through The Competing Values Framework, will 
challenge them to adopt a new way of thinking that will increase their impact as leaders and managers. For over 60 years the competing values of their framework has been used by the world and well-known commercial companies to drive innovation, create high-performance cultures, explore and expand into old and new markets, and improve overall quality through the training programs to enhance their work and their staff. This training program explores the critical components of effective management and leadership in order to learn how to make better decisions under pressure, improve a better and better leadership approach in increasingly complex and mixed environments like UAE, develop talent more effectively and lead with more creativity, energy, and intensity. The idea of cultivating and leveraging individual and organizational capabilities will be emphasized throughout the best training program. Then, this would emerge with an action plan to help them advance their career and drive positive results in their organization wherever they are and in any administrative site.

\subsection{Research Terms}

1- Human Resources Management is working for organization's powers or human resources management. It specializes in attracting staff, selection, training, evaluation and rewarding employees. It also follows the leadership and culture of the organization to ensure its compliance with labor laws. If the staff is willing to conduct collective negotiations with human resources management, their role is the initial communication with the staff representatives (usually with trade unions).

2- Training: Whether the organization seeks to train its individuals, employed or enrolled in work, to increase knowledge, skills or abilities or ideas necessary for the performance of specific actions in accordance with its goals or it intends to change the behavior of workers through organizational procedure in order to increase and improve their efficiency and performance, especially management training of supreme departments in any institution.

3- Banks: Commercial banks represent the largest section in the commercial system sector in the second division in the sequence. The central bank proceeds out of control and monitor bank activities and affect their ability to create cash deposits. Commercial Bank was identified as an institution that deals with debt or credit and bank deposits called gets the debts of third parties and gives against which promises to pay on demand or after a short-term. This credit provided by the bank falls within its assets because it really represents it to others.

\section{4- Efficiency:}

The ability to achieve goals activates or does things properly.

\section{5- The performance :}

A set of activities performed by an individual, who reflects the level of efficiency in accomplishing the tasks and duties entrusted to him.

Term productivity is known as a measure of the ability of enterprises to achieve the output of the input, also known as the possibility of achieving the largest possible amount of output from a given quantity of inputs.

6- Emirates College of Technology which provide courses in teaching and training in the same field and other courses like Management, Human Resources and financial studies.

Emirates College of Technology was founded in the center of Abu Dhabi and it showed rapid growth and development in 1993 after receiving recognition from the Ministry of Education in the United Arab Emirates. It was launched to keep pace with developments in technology and business of modern life: it is the day to prove it as one of the oldest institutions that has a long proud history in the region.

In addition, the college not only provides bachelors' and diploma programs in many disciplines but it also prides itself by providing bachelor's programs in business, science and financial management, public relations and HRM (in English) as well as health information management and industrial management. The Emirates College of Technology is given a golden chance to its students to capture knowledge that will help them meet the challenges of the challenging developments in the local and international markets.

Emirates College of Technology is accredited by the Ministry of Higher Education and Scientific Research in the United Arab Emirates. It boasts a teaching crew that contains the authors from more than 16 different countries of the world and they are the people with a great deal of enormous contribution to the development of knowledge, professional service, teaching and supervision.

The college keeps the pace with the culture of the region. The lectures are held in three separate buildings and each one has a high number of students. The students can also choose shifts consistently within: weekend-days morning and evening, which helps them to adapt their programs according to the curriculum for the need of all students. 
Emirates College is aware of the fact that the activities of students outside the auditorium are an essential part of the experience. They enjoy the college student community, a medley of environment, where they are configured for long-term friendships and integrated into a variety of social, cultural and sporting activities to enable them to develop their skills and the abilities to become downright professionals.

On the other hand, the programs offered as well as the future programs provide a good opportunity to the students who prefer to study in the country with a view to travelling abroad to get a diploma or bachelor's degree. Emirates College has enabled its graduates to complete their higher studies in bachelors that is furnished in the same colleges or in the local universities, Arab or Western, or in Canada, America and other countries with various programs.

With a platform for high-quality curriculum in addition to the body of distinctive teaching, infrastructure and facilities of the highest level, make room for students to have big dreams. It lets them share their unique talents, and makes them feel proud of being the part of a fertile culture.

There are several colleges and universities in Abu Dhabi and in the rest of the state of the emirates that are all able to offer diverse academic programs and trainings. They enjoy a high reputation for efficiency, and has copious administrative and academic competencies

7- About Emirates Institute for Banking and Financial Studies, which is specialized in the training of bank employees and other people of the UAE banking and financial study and also provides bachelors' in more than one specialty.

Emirates Institute, specifically for National Banking and Financial Studies, is a foundation that is fundamentally interested to train commercial bank employees. It aims to contribute to the strategic plans and furnishes economically in the UAE country through the development of human resource by increasing their performance through the technological process for the last several years. It has also participated in the teaching programs according to British and Canadian Academic systems and has such a reputed educational, institutional experiential process that is eligible to do the international teaching work and academic training. It has progressed rapidly through the effective use advanced technologies and the evolution of this institution has been honorably recognized by the ministry of higher education and it has initiated three branches in the United Arab Emirates.

Emirates Institute for Banking and Financial Studies was founded in 1983 which provides educational programs, training courses, banking training services and financial solutions at a world-class level in three centers and it occupies a strategic planning system in Sharjah, and Abu Dhabi and Dubai. As a part of the commitment to resettlement initiative, Emirates Institute for Banking and Financial Studies in UAE centers supports UAE nationals by providing high-level training facilities and by encouraging job growth in the financial services and banking sector.

It was the integration of the Emirates Institute for Banking and Financial Studies worldwide with various institutes and leading universities of the world that are developing better programs and courses in the field of banking and financial services in UAE.

The Emirates Institute for Banking and Financial Studies has come forward in bringing about a major development in the career of thousands of students and professionals, who, working in the field of banking and finance, has been supported from trained academics and leading experts.

Emirates Institute for Banking and Financial Studies has seen significant growth over the past years, especially in terms of the number of students, trainees and academic training programs, websites and members of the faculty, staff, alumni and others.

Every year, the institute receives thousands of students and trainees who are interested in learning and training from across the UAE. It provides a wide range of educational opportunities in the banking and financial support through the experiences and research based programs and it dispenses the high-end facilities in the field in UAE.

\subsection{Research Problem}

Through my work, both in teaching and management training in UAE, now and before, I strongly believe that the research problem stems from the weaknesses and deficiencies in the training programs followed by inadequate productivity in banking institutions in the UAE. According to the developments and technological changes and renewable rapid makes, it is imperative to render follow-up to the organizations and the preparation of training programs. It is feasible to limit the research problem by exploring the following questions:

What is the role of training in increasing the efficiency of staff performance?

What extent of benefit from training courses obtained by the staff? 
What is the appropriate training period to take advantage of high efficiency training courses?

\subsection{The Research Aims}

- To identify the reality of the training process in productivity and the banking sector in the United Arab Emirates - Abu Dhabi and Dubai and whether those institutions concerned with the development of human resources, especially the middle and upper class and the administration. It also aims to shed light on the following points:

- Identify the convictions of those who are the in charge of the management of these institutions on the issue of training and how much importance they attach to it for the benefits of their staff.

- Identify deficiencies or weaknesses in the existing training programs and their negative effects on the performance of employees, leaders and management, the makers of the administrative decisions.

- To determine, if the management of these institutions follow-up with the environmental changes and take them into account when preparing for training programs.

\subsection{The Importance of the Study}

The importance of this research is the importance of the subject of training and human resource development through these things:

1- The growing value of this subject as a result of the need for training programs and the need to cope with the nature of the economic, environmental and technological changes demands that it should be treated in a befitting manner. Furthermore, the growth of a competitive mass marketing in this area and the developments in the surrounding environment so as to improve the performance of individuals and management calls for earnest handling.

2- Taking into account the subject of cost, the cost of training is much less than the cost of the negative performance of leaders and management and unqualified personnel in the long run.

\subsection{Reliability and Validity of the Tool}

The veracity of the material and the content of the tool for research questionnaire were ascertained after the thorough inspection by the supervisor of expert scientific research. In the second place it was presented for inspection to a group of specialists and experts in the field of scientific research.

\section{Research Hypothesis}

In order to sniff out proper answers and solutions to the scientific problems that were raised in this research and to achieve the desired goals, the research seeks to test the validity of the following hypothesis

\subsection{The Hypothesis}

H1: - A statistically significant relationship between human resources and training needs exists in banking sectors in the city of Abu Dhabi and Dubai.

H2 Secondly, a statistically significant relationship between human resources and defining the goals of training programs have existed in banking sectors in the city of Abu Dhabi and Dubai.

H3:- Thirdly, there is a statistically significant relationship between human resources and the implementation of training in banking sectors in the city of Abu Dhabi and Dubai.

H4:- Lastly, A statistically significant relationship is found between human resources and the evaluation and follow-up of the effectiveness of training in banking sectors in the city of Abu Dhabi and Dubai

There is a statistical significance of the relationship between training and an increase in the efficiency of staff performance.

There is a statistically significant relationship between the training period and efficiency.

There is statistically major link between training and the advancement of staff performance.

There are considerable differences between the training and development of the staff performance relationship and branches for this hypothesis is the following assumption: 


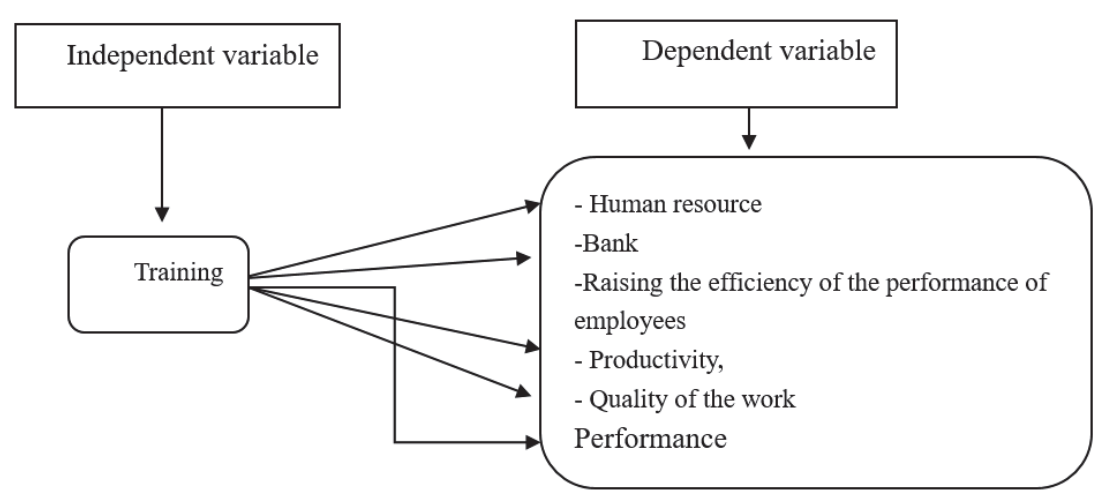

Figure 1. The research variables

\subsection{Research Methodology}

Research includes two aspects:

1- The theoretical side: the adoption of the approach and descriptive analysis takes advantage of references, books and articles on the subject of the search.

2- The practical side: to ensure a field study of the reality of the training programs used by commercial banks to collect data. The information related to the data was collected through a questionnaire that was designed and distributed to the employees in a number of banks in the city of Abu Dhabi - United Arab Emirates.

\subsection{Societies and the Research Sample}

1- Five commercial banks in the city of Abu Dhabi and the Emirates Institute for Banking and Financial Studies in Abu Dhabi, Sharjah and Dubai: banks and training centers are:

2- Union National Bank, 2- Emirates Bank, 3- Bank of Sharjah, 4- First Gulf Bank, And 5- Abu Dhabi National Bank .

3- Emirates Institute for Banking and Financial Studies (EIBFS)and Emirate College of Technology (ECT)

\subsection{Statistical Analysis Methods and Stability of Scientific Research Tool}

The data were subjected to statistical analysis using the following methods:

Statistics and descriptive methods: (averages, standard deviation)

Statistical methods evidentiary: (Pearson correlation coefficient, test z)

The most important findings of the study revealed the following facts:

1. There is a relationship between the administrative development and all of the functional up gradation process. Transfers and operations that take place on the same administrative level between the administrative leadership, and the plans to develop for follow-up jobs in these banking institutions were selected.

2. The lack of accurate and complete information for management development plans and career development has been observed. The bank management is not getting enough information about the programs in order to help managers to let them know the importance of management development and opportunities available at management level.

3. The banks that have been subjected to the study unanimously agree that the development contributes to increase the practical and theoretical capabilities and helps acquire new job skills in the job field of the candidate. It helps them to carry out their work more efficiently.

4. Need and importance of training is not identified in a scientific way, despite the awareness of the importance of the management of the process.

5. The large number of trainees under the supervision of one coach reflects negatively on the quality of the training process.

6. Training process quality reflected positively on the quality of banking services. 
7. The presence of a statistic significance of the study, the effects of human resources management policies and the efficient performance of employees were observed.

8. It was pointed out that the incentives and financial rewards in the system of the commercial banks it doesn't help individuals who attended the training programs. The financial incentives in previous years were much better, according to some opinions.

\section{Data Analysis}

This study aims to assess the impact of human resources in identifying training needs for the bank staff, defining the goals of training programs, increasing the efficiency of the performance of the staff, the implementation of training and evaluation and follow-up the effectiveness of training in bank sectors in UAE and Abu Dhabi. Therefore, the results of the study have been presented and analyzed in this section. The study uses a descriptive analysis to describe the training needs of the responding employee, requirements and abilities through training programs. The research hypothesis were presented and tested by ANOVA and it was used to measure the differences between the sample groups, Pearson Correlation was used to explore the correlation between the study variables (dependent and independent variables), and Stepwise multiple regression was used to test the hypothesis.

\subsection{Stability of the Study Tools}

Stability tools of this study have been tested by using Cronbach's alpha, in table no (1) that shows that the values are higher than 0.64 which mean that the study tool is stable. Dimension Alpha's value Identifies that the training need is 0.79 . It also defines that the need of the training program is 0.82 that implies the implementation of training programs is 0.74 and the follow-up of training effectiveness 0.83 , while the total is 0.86 .

Table 1. Characteristics of the respondents

\begin{tabular}{llc}
\hline No & Dimension & $\begin{array}{l}\text { Alpha's } \\
\text { value }\end{array}$ \\
\hline 1 & Identify training needs & 0.79 \\
2 & Identify the Training programs needed & 0.82 \\
3 & The implementation of training & 0.74 \\
4 & The follow up on training effectiveness. & 0.83 \\
\hline \multicolumn{2}{c}{ Total } & 0.86 \\
\hline
\end{tabular}

Table (1) indicates that $79.17 \%$ of the study samples were male and the remaining $(20.83 \%)$ respondents were female. The study findings show that the most of the bank staff of the listed bank is for men and the reason might be to the job nature of these sectors. It also shows that $40.05 \%$ of the samples are older than 45 years, and $35.37 \%$ aged from 35- and less than 45 , which gives us $24.76 \%$ between the ages of 25 - and less than 35 , and $3.63 \%$ under the age of 25 . The findings of this table show that the majority of the respondents lie in the third level, few of the respondents were from the second level which indicates that $39.05 \%$ of the samples are holding a Bachelor degree, $30,4 \%$ of them hold a master and, $20.95 \%$ of respondents with a college diploma, and $8.57 \%$ of them hold a high school diploma, and $0.95 \%$ of them hold a PhD. So the most respondents had a Bachelor Degree. It means that most of the workers who work in this sector are graduates and this is a clear evidence to validate the current study. .

Table 2. Description of the characteristics of a study sample

\begin{tabular}{clll}
\hline Personal Dimension & Variable & Frequency & Percentage\% \\
\hline Gender & Male & 56 & 61.17 \\
& Female & 44 & 38.83 \\
& Less than 25 & 6 & 4.11 \\
& 25 - less than 35 & 28 & 24.76 \\
& 35 - less than 45 & 36 & 32.38 \\
& Equal or more than 45 & 43 & 39.05 \\
& Secondary & 25 & 20.95 \\
& Diploma & 33 & 30.48 \\
BS & 43 & 39.05
\end{tabular}




\begin{tabular}{lll} 
Master & 10 & 8.57 \\
PhD & 3 & 0.57 \\
Less than 5 & 21 & 19.05 \\
$5-10$ & 14 & 11.43 \\
$11-15$ & 19 & 17.14 \\
More or equal 15 & 49 & 52.38 \\
Supervisor & 4 & 1.90 \\
Chief supervisor & 6 & 5.71 \\
Managers and Staff & 30 & 28.75 \\
\hline & $\mathbf{6 7}$ & $\mathbf{6 3 . 8 1}$ \\
\hline
\end{tabular}

\subsection{Stability of the Study Tools}

Table (2) shows that $61.17 \%$ of the study samples are male and the remaining (38.83\%) respondents are female. These findings show that the most employees in the listed banks are men and the reason might be the job nature of the sector. It also showed that $39.05 \%$ of the sample are equal to or older than 45 years, and $32.38 \%$ aged from 35 - and less than $45,24.76 \%$ are between the ages of 25 - and less than $35,3.81 \%$ are under the age of 25 .The findings of this table reveal that the majority of the respondents lie in the third level, few of the respondents are from the second level and it indicates that $39.05 \%$ of samples are holders of a Bachelor degree, $30,49 \%$ of them have a diploma, $20.95 \%$ of respondents are with a high school diploma, and $8.57 \%$ of them possess a master's degree, and $0.95 \%$ of them hold a $\mathrm{PhD}$. So the most respondents who work in firms are graduates and this is a clear evidence for the validity of the study. This Table (2) clarifies that $52.38 \%$ of the of the respondents have an experience of 15 years or more, $19.05 \%$ of respondents have less than 5 years' experience, and $17.14 \%$ have experience ranig from 11 to 15 years., and $11.43 \%$ of them range in experience between 5-10 years. The findings showed that the least respondents are from the last level. The Majority of the respondents whose experience is more than 15 years, illuminate that there are $63.81 \%$ of the sample of the study is staff, $28.57 \%$ are Chiefs, $5.71 \%$ are serving as Deputy Director and $1.90 \%$ of those serving as Director.

Table 3. arithmetic averages, standard deviation, value and significant observation level in defining training.

\begin{tabular}{lllll}
\hline Phrases & $\begin{array}{l}\text { Arithmetic } \\
\text { average }\end{array}$ & $\begin{array}{l}\text { Standard } \\
\text { deviation }\end{array}$ & T value & $\begin{array}{l}\text { Significance } \\
\text { observation } \\
\text { level }\end{array}$ \\
\hline $1 \quad \begin{array}{l}\text { Human resources management help in defining that } \\
\text { the training needs at the unit level }\end{array}$ & 3.74 & 1.16 & 5.21 & \\
2 & $\begin{array}{l}\text { Human resources management helps in identifying } \\
\text { bank training needs in the long term. }\end{array}$ & 3.06 & 1.54 & 0.32 \\
$3 \begin{array}{l}\text { Human resources management helps in identifying } \\
\text { training needs for the short term in the banking } \\
\text { sectors. }\end{array}$ & 1.65 & 4.90 \\
$4 \begin{array}{l}\text { Human resources management helps in identifying } \\
\text { training requirements according to the job } \\
\text { description of the banking sectors. }\end{array}$ & 0.74 & 10.75 & \\
$5 \begin{array}{l}\text { Human resources management provides training } \\
\text { requirements for bank employees. }\end{array}$ & 4.17 & 0.64 & 14.42 & \\
$6 \begin{array}{l}\text { Human resources management helps in identifying } \\
\text { individual needs to do the required job in the bank. }\end{array}$ & 2.43 & 1.30 & -3.63 & \\
\hline Total & $\mathbf{3 . 5 1}$ & $\mathbf{0 . 6 2}$ & $\mathbf{6 . 7 1}$ & \\
\hline
\end{tabular}

Table (3) shows that's there is a statistically noteworthy link between human resources management and training needs in banks in the city of Abu Dhabi and Dubai. As table 3 shows that, with the exception of paragraphs 2 and 6 , all paragraphs got arithmetic mean greater than 3.00 and got significant observation level less than 0.05 , i.e. all those paragraphs are of statistical significance. Paragraph No. 5 came first with 4.17 arithmetic mean, which 
means that the greater impact of the human resources management is in the area of providing the requirements for training. Paragraph 3 which measures human resources management is to assist and identify bank training needs in the short term that came in last place among the statistically accepted paragraphs 3.65 arithmetic mean. Paragraph 2, which measures the help of human resources management in identifying required training needs in the long run, although it got a arithmetic mean greater than 3.00 but it got an observation level greater than 0.05 , i.e. it's not statistically significant. Paragraph 6 , which measures human resources management, is to assist and identify individual needs which got arithmetic mean less than 3.00 and it is not statistically significant. All paragraphs unanimously got 3.51 arithmetic mean, which is greater than 3.00 , and 0.00 observation levels, which is less than 0.05 , i.e. Statistically significant relationship between human resources management and training needs in bank sectors in both Abu Dhabi and Dubai.

Table 4. Arithmetic average, standard deviation, show the value and observation level related to relationship between training, goals and performance efficiency of the bank staff.

\begin{tabular}{|c|c|c|c|c|c|}
\hline No & $\begin{array}{l}\text { Phrases } \\
\text { The relationship between training and increasing } \\
\text { the performance efficiency of the staff and the } \\
\text { goals of training programs }\end{array}$ & $\begin{array}{l}\text { Arithmetic } \\
\text { average }\end{array}$ & $\begin{array}{l}\text { Standard } \\
\text { deviation }\end{array}$ & $\begin{array}{l}\text { T } \\
\text { value }\end{array}$ & $\begin{array}{l}\text { Significance } \\
\text { observation } \\
\text { level }\end{array}$ \\
\hline 7 & $\begin{array}{l}\text { The training program is linked to the practical } \\
\text { work in the bank }\end{array}$ & 3.84 & 1.16 & 6.48 & 0.00 \\
\hline 8 & $\begin{array}{l}\text { I reflected my participation in the training } \\
\text { program in the practical application in the bank. }\end{array}$ & 3.02 & 1.52 & 0.08 & 0.74 \\
\hline 9 & $\begin{array}{l}\text { I developed my knowledge and career evolved in } \\
\text { the bank as a result of the training }\end{array}$ & 3.93 & 1.04 & 8.46 & 0.00 \\
\hline 10 & $\begin{array}{l}\text { My participation in the training program helped } \\
\text { me to improve my performance and career at the } \\
\text { bank. }\end{array}$ & 3.91 & 1.07 & 7.82 & 0.00 \\
\hline 11 & $\begin{array}{l}\text { Increasing the size of my achievements in my } \\
\text { work as a result of practical training programs } \\
\text { already taken. }\end{array}$ & 3.89 & 1.10 & 7.44 & 0.00 \\
\hline 12 & $\begin{array}{l}\text { The evaluation of the training of equipment } \\
\text { (Software) considers appropriate in terms of the } \\
\text { objectives that have been developed and } \\
\text { previously selected for the organization of } \\
\text { training programs }\end{array}$ & 3.82 & 1.16 & 6.48 & 0.00 \\
\hline Total & & 3.74 & 0.80 & 8.32 & 0.00 \\
\hline
\end{tabular}

Table (4) shows there is a statistically significant relationship between human resources and defining the goals of training programs in bank sectors in the city of Abu Dhabi and Dubai. As table 4 shows that, with the exception of paragraphs 8 , all paragraphs got arithmetic average greater than 3.00 and got significant observation level less than 0.05 , i.e. all those paragraphs are of statistical significance. Paragraph No. 9 , which measures human resources management help in analyzing and processing goals to determine the quality of training programs came first with 3.93 arithmetic mean. Paragraph 12, which measures latest software that are suitable and appropriate in terms of the objectives that have been previously selected for training programs in Abu Dhabi and Dubai bank sectors come in the last place, among the statistically accepted paragraphs with 3.82 arithmetic average. Paragraph 8, which measure the work of the human resources management to determine the goals through training programs, although it got an arithmetic mean greater than 3.00 but it got an observation level greater than 0.05 which is not statistically significant. All paragraphs without exception got 3.74 with arithmetic mean, which is greater than 3.00 , and 0.00 observation levels, which is less than 0.05 , The data shows a statistically significant relationship between human resources management and defining the goals of the training programs in the banking sectors in both Abu Dhabi and Dubai with a relationship between a training and its competence. 
Table 5. Shows the arithmetic average, standard deviation, the value and private observation level related to setting the goals of training programs

\begin{tabular}{|c|c|c|c|c|c|}
\hline & $\begin{array}{l}\text { Phrases } \\
\text { The relationship between training programs and its } \\
\text { competence and the goals of training programs }\end{array}$ & $\begin{array}{l}\text { Arithmetic } \\
\text { average }\end{array}$ & $\begin{array}{l}\text { Standard } \\
\text { deviation }\end{array}$ & $\begin{array}{l}\mathrm{T} \\
\text { value }\end{array}$ & $\begin{array}{l}\text { Significance } \\
\text { observation } \\
\text { level }\end{array}$ \\
\hline 13 & $\begin{array}{l}\text { Human resources management assists training } \\
\text { programs and the innovation and the renewal and } \\
\text { modernization in the work field }\end{array}$ & 4.03 & 1.02 & 9.34 & 0.00 \\
\hline 14 & $\begin{array}{l}\text { Human resources management and its } \\
\text { implementation based on identifying training } \\
\text { methods and courses leads us to the continued } \\
\text { evaluation of the performance of the bank. Works. }\end{array}$ & 3.84 & 1.11 & 6.93 & 0.00 \\
\hline 15 & $\begin{array}{l}\text { Human resources management increases staff } \\
\text { efficiency through training programs to become } \\
\text { aware through training programs on some legislation } \\
\text { and administrative laws that should be taken in the } \\
\text { banking system. }\end{array}$ & 3.65 & 1.18 & 5.16 & 0.00 \\
\hline 16 & $\begin{array}{l}\text { Human resource management increase bank } \\
\text { efficiency through training programs have helped us } \\
\text { in achieving our life skills that fall within the } \\
\text { banking work and banking systems. }\end{array}$ & 3.75 & 1.04 & 6.83 & 0.00 \\
\hline 17 & $\begin{array}{l}\text { Human resources management increases the bank } \\
\text { productivity through the implementation of training } \\
\text { programs helped improve our relationships and the } \\
\text { treatment with superiors and colleagues in the bank } \\
\text { which I work with. }\end{array}$ & 3.65 & 1.21 & 4.94 & 0.00 \\
\hline 18 & $\begin{array}{l}\text { Equipment (Hardware) used in training programs to } \\
\text { achieve the reason of training, implementation and } \\
\text { contributed to the improvement and orientation } \\
\text { towards the banking profession. }\end{array}$ & 3.74 & 1.09 & 6.16 & 0.00 \\
\hline 19 & $\begin{array}{l}\text { There is a written guide to use procedures on how to } \\
\text { use the human resources management in training } \\
\text { programs and to increase staff efficiency through } \\
\text { training considered in the banking system. }\end{array}$ & 3.60 & 1.22 & 4.51 & 0.00 \\
\hline 20 & $\begin{array}{l}\text { There is no difficulty in dealing with the human } \\
\text { resources management when implementing training } \\
\text { programs to increase bank staff efficiency. }\end{array}$ & 2.73 & 1.57 & -1.64 & 0.00 \\
\hline 21 & $\begin{array}{l}\text { Human resources management affects the staff } \\
\text { commitment to training programs to increase the } \\
\text { bank productivity }\end{array}$ & 3.98 & 1.07 & 8.59 & 0.10 \\
\hline \multirow[t]{2}{*}{22} & $\begin{array}{l}\text { There is no resistance from some staff to the update } \\
\text { on the applied training programs toward Equipment } \\
\text { (Hardware) used in training programs to achieve the } \\
\text { reason of training implementation and contributed to } \\
\text { the improvement and orientation in the banking } \\
\text { profession. }\end{array}$ & 2.92 & 1.44 & -0.67 & 0.00 \\
\hline & Total & 3.57 & 0.68 & 7.98 & 0.50 \\
\hline
\end{tabular}

Table no (5) shows that there is a statistically significant relationship between human resource management and the implementation of training in banking sectors in the city of Abu Dhabi and Dubai. Table 5 shows that, with the exception of paragraphs 20 and 22, all paragraphs got arithmetic mean greater than 3.00 and got significant 
observation level less than 0.05 , i.e. all those paragraphs are of statistical significance. Paragraph No. 13 measures the work of human resource management to maintain training programs that come first with 4.03 arithmetic mean. Paragraph 19 has a written guide to the procedures on how to use the human resources management system in enhancing training programs that comes in the last place among the statistically accepted paragraphs with 3.60 arithmetic mean. Paragraph no 20 measure the difficulties in dealing with the human resources when implementing training programs in banking sectors and it got 3.00 with arithmetic mean but it's not statistically significant. Paragraph No. 22, which measure the resistance from some staff to the applied training program update, got 3.00 with the arithmetic mean. However, it's not statistically significant. All paragraphs with one accord got 3.57 with arithmetic mean, which is greater than 3.00 , and 0.00 observation level, and less than 0.05 . It reveals that there is a statistically significant relationship between human resources and implementation of training in the banking sectors in Abu Dhabi and Dubai.

Table 6. Statistically remarkable association between human resources and training evaluation

\begin{tabular}{|c|c|c|c|c|c|}
\hline & Phrases Evaluation and follow up of training efficiency & $\begin{array}{l}\text { Arithmetic } \\
\text { average }\end{array}$ & Deviation & $\begin{array}{l}\mathrm{T} \\
\text { value }\end{array}$ & $\begin{array}{l}\text { Observation } \\
\text { level }\end{array}$ \\
\hline 23 & $\begin{array}{l}\text { The relationship between training and improving the } \\
\text { performance of employees one of the elements } \\
\text { considers by human resource management }\end{array}$ & 1.95 & 1.46 & -6.33 & 0.00 \\
\hline 24 & $\begin{array}{l}\text { Standards to measure the effectiveness of training one } \\
\text { of the concerns of human resource management }\end{array}$ & 3.84 & 1.08 & 6.88 & 0.00 \\
\hline 25 & $\begin{array}{l}\text { People working on the human resources management } \\
\text { have different specialization to deal with training in the } \\
\text { bank. }\end{array}$ & 3.66 & 1.19 & 4.89 & 0.00 \\
\hline 26 & $\begin{array}{l}\text { Human resources personnel have a periodically training } \\
\text { to develop abilities, capabilities, and bank staff skills }\end{array}$ & 3.71 & 1.04 & 6.04 & 0.00 \\
\hline 27 & $\begin{array}{l}\text { The human resources management organized training } \\
\text { programs to fit bank staff. }\end{array}$ & 3.59 & 1.22 & 4.31 & 0.00 \\
\hline 28 & $\begin{array}{l}\text { Training courses to increases job satisfaction for staff } \\
\text { working in the bank }\end{array}$ & 3.71 & 1.11 & 5.64 & 0.00 \\
\hline 29 & $\begin{array}{l}\text { Human resources management making a competitive } \\
\text { program for bank staff to fill posts in the future }\end{array}$ & 1.88 & 1.21 & -8.08 & 0.00 \\
\hline 30 & $\begin{array}{l}\text { Human resources management follows a certain } \\
\text { methodology in recruiting trainee to fit the bank job } \\
\text { responsibilities }\end{array}$ & 3.98 & 1.09 & 7.86 & 0.00 \\
\hline 31 & $\begin{array}{l}\text { Equipment (Hardware) is appropriate for training } \\
\text { organization to fit training programs needed by the } \\
\text { bank }\end{array}$ & 3.90 & 1.26 & 6.88 & 0.00 \\
\hline 32 & $\begin{array}{l}\text { Equipment (Software) is appropriate and available in } \\
\text { the for training organization to help you learn all what } \\
\text { you need from your training courses. }\end{array}$ & 3.90 & 1.26 & 6.32 & 0.00 \\
\hline 33 & $\begin{array}{l}\text { Human resources management can detect the } \\
\text { deficiency and difficulties that the bank suffers could } \\
\text { help you to solve problems }\end{array}$ & 3.88 & 1.06 & 7.29 & 0.00 \\
\hline 34 & $\begin{array}{l}\text { Is the use of the human resource standard tools will } \\
\text { compete to monitor working staff behavior and } \\
\text { attitudes after implementing the training courses. }\end{array}$ & 1.92 & 1.31 & -7.25 & 0.00 \\
\hline & Total & 3.34 & 0.55 & 5.20 & $\mathbf{0 . 0 0}$ \\
\hline
\end{tabular}

Table (6) shows that there is a statistically remarkable association between human resources and the follow up training evaluation of effectiveness of banking employees in the city of Abu Dhabi and Dubai. Table 6 also shows, with the exception of paragraphs 23, 29 and 34, that all paragraphs got arithmetic mean that is greater than 3.00 and got significant observation level less than 0.05. All of these paragraphs are of statistical significance. Paragraph No. 30 shows the extent to which human resources adopt a methodology in the employment of trainees which come first with 3.98 arithmetic mean. Paragraph 27 highlights that human resources management organizes training programs to fit bank staff in the last place among the statistically 
accepted paragraphs with 3.59arithmetic mean. Paragraph 23 measures the relationship between training and improving the performance of employees. One of the elements considered by human resource is continuously providing periodic reports monitoring training effectiveness. It got a 3.00 arithmetic mean which is not statistically significant On the other hand, paragraph No. 29, measure human resources, adapting a competitive program for bank staff to fill posts in the future and making a competitive and effective program for staff to fill job posts with 3.00 arithmetic mean which is not statistically significant. Paragraph 34 measures the standard tools of monitoring staff behavior at work after implementing the training programs and it got 3.00 with arithmetic mean which is not statistically significant. All paragraphs, in complete agreement got 3.34 with the arithmetic mean. It is greater than 3.00 and 0.00 observation level, which is less than 0.05 , with statistically significant relationship between human resources and the evaluation and follows up of training efficiency in Abu Dhabi and Dubai banks.

\section{Research result and finding}

In addition to the descriptive analysis that has been applied in order to understand better the characteristics of the study, some statistical tests were also used to examine and explain the relation between the independent variable (training) and dependent variables, such as Human recourses, Banks, Raising the efficiency of the performance of employees and Productivity,

\section{Following is a Review of the Results}

1. There is a statistically significant relationship between training and human resource needs in banks in Abu Dhabi and Dubai cities. The study identifies training needs of the banking sector and helps to identify the needs of training in the banks selected in the study for short term, commensurate with the job description, and provides conditions for training. However, it does not help to identify training needs of the banks in the long term, and does not help to determine individual needs.

2. There is a statistically significant relationship between training and defining the goals of training programs in the banking sector in the city Abu Dhabi and Dubai, where this system works to clarify goals through human resource and training programs, it also helps to analyze and process and goals to determine the quality of the training programs. Moreover, it helps to achieve staff training requirements, and the user of the equipment (Hardware) is considered appropriate in terms of the objectives that have been developed and previously selected for bank training programs. Nonetheless, it does not work on measuring goals through training programs and human resources.

3. There is a statistically notable link between training and human resources and the implementation of training in the city of Abu Dhabi and Dubai banks. Here, it manages the implementation of training programs that are based on the ways of training which were originally identified to increase the efficiency of bank staff through necessary training programs. It increases the efficiency of the banks through training and expands the productivity. The equipment and hardware used in training programs help in the implementation of effective training. There is a written guide to the procedures used by training institution and how to use the system to practically affect the obligation of staff through training programs. However, there is a difficulty in dealing with the system while implementing the training program through human resource, and there is resistance by some of the staff members to update that training program when applied by the human resource department.

4. There is a statistically significant relationship between training and human resources management and training evaluation and the follow up of the effectiveness of the banking sectors in the city of Abu Dhabi and Dubai. The place where the banking system provides standards for measuring the effective training to the working personnel who have different specializations, demonstrates better output. Periodical training has a vital role to develop the abilities and skills of the workers. Indispensable training programs for the organization increase job satisfaction for bank staff who learn the system to use new methodologies in the training centers like hardware, equipment and software and so on. Used in a way with the requirements of the training programs, and used the software to be appropriate to the requirements of the training programs through the human resource department, the system of human resource discovers there is difficulties and mistakes the banks suffer from. But the human resource system and the training department do not provide regular or special reports that cover monitoring training effectiveness and does not work competitively to employ staff to vacant posts; the human resource system and training department does not use standard tools to continue working behavior after the implementation of training programs implemented.

5. There is a statistically significant connection between the training and human resource management productivities. If the training does not pay attention to the quality of service, and does not give adequate instructions to the employees, its effect is nullified. If it does not address the challenging situation created by 
economic problems in the country these days, it shows a lack of familiarity with the regulations and laws and its effect is reduced to the point of nothing. Furthermore, it generates the ignorance of the advantages and disadvantages of banking products, frequent inconvenience of sales representatives who try to force the customer to buy a new product in order to obtain the maximum amount of the commissions.

6. On the other hand, for self-development the bank's academy is working to support the employees in the improvement of performance and enhancement of skills and abilities through a series of innovative and sophisticated ways.

\subsection{Recommendations}

1. Banks must provide personal development plans along with skills enhancement programs to double the use of time. The trainees must be exposed to learn communication skills and a chance to plentifully communicate with others. Training should impart better presentation skills, and workshops should refine professional development to enhance the intercommunication skills to support the participants to converse effectively with their managers about their career plans. They must be encouraged to take responsibility for the development of their careers in a manner that fits their individual needs. They can work on the support of experienced leaders in the development of a clear vision and an integrated hands-on in-service training. The training on project management supports the understanding of the definition and the use of project management as well as the role and responsibilities of the strategic projects scams.

2. Banks must identify the tasks and duties of each employee and it should be determined before sending any staff to the training courses which must correspond to his nature of the job. This practice can help in achieving optimum results from training courses.

3. Banks in UAE must consider training conditions like training time, location, facilities, and materials available and the number of trainees in each batch.

4. Banks must work on improving skills and performance through taking into account the age, sex, educational level and experience of the trainees.

5. A bank must invest in the development of the skills of its workers. There are a number of ways to train the staff, but the need for more attention from the commercial banks need to pay more attention to improve the career bring out the best performance in creative ways conforming the needs of customers or clients.

\section{References}

Al-Azzawi, \& Awad, A. (2009). The development of human resources management, concept, strategy, organizational location, Oman, Dar Yazouri, Jordan.

Armstrong, M. (2006). Performance Management: Key Strategies and Practical guide lines. ( ${ }^{\text {rd }}$ Ed.), Kogan.

Armstrong, M. (2006). Strategic Human Resource Management: A Guide to Action. London: KoganPage.

Atkinson, J., \& Feather, N. (1966). Theory of Achievement Motivation, New York, NY, Wiley.

Banjo, S. A. (2010). Human resources management, Lagos: Saban Publishers.

Egwurudi, P. C. (2008). Job Satisfaction: Effect on job characteristics. Unpublished Mcs Dissertation University of Lagos, Nigeria.

Evans, M. G. (2006). Organisational behavior: The central role of motivation. Journal of Management, 12(2), 203.

Eze, N. (2009). Sources of Motivation among Nigerian managers. Journal of Social Psychology, 125, 341-345.

Jibowo, A. A. (2007). Effect of Motivators and hygiene factors, on job performance among extension workers in the former.

Kissler, G. (2008). Fundamentals of Human Resource Management, International Edition, Rearson.

Kumar, K. (2009). Linking the 'Big Five' Personality Domains to Organizational Citizenship Behavior. $\begin{array}{lllll}\text { Retrieved February 8, 2013, from } & \text { 8, }\end{array}$ http://www.ccsenet.org/journal/index.php/ijps/article/download/2593/3835

Mani, V. (2010). Development of Employee Satisfaction index scorecard. European.

Miner, J. (2006). Organizational Behavior 4: From Theory to Practice. Armonk, NY: M. E. Sharpe.

Redman, T., \& Wilkinson, A. (2008). Contemporary Human Resource Management: Text and Cases. (3rd Ed.), Pearson. 
Tai, J. H., Vantage, A. M., \& Abadi, F. H. (2006). Human resource management, strategic, integrated entrance, Oman, Warraq for Publishing and Distribution, Jordan.

The Joint Effects of Personality and Workplace Social Exchange Relationships in Predicting Task Performance and Citizenship Performance. Retrieved February 9, 2013, from http://cqonline.org/papers/JAP\%20Kamdar\%20and\%20Van\%20Dyne\%202007.pdf

Torrington, D., Laura, H., \& Steven, T. (2008). Fundamentals of Human Resource Management Managing People at work, Pearson, USA.

Tzeng, H. (2002). The influence of nurses' working motivation and job satisfaction on intention to quit: an empirical investigation in Taiwan. International Journal of Nursing Studies, 39(8), 867-878.

Wood, S., \& de Menezes, L. (1998). High commitment management in the UK: evidence from the Workplace Industrial Relations Survey and Employers. Manpower and Skills Survey of Human Relations, 51(4), 485-515.

Yazdani, B. O., Yaghoubi, N. M., \& Giri, E. S. (2011). Factors affecting the Empowerment of Employees. European Journal of Social Sciences, 20(2), 267- 274.

\section{Copyrights}

Copyright for this article is retained by the author(s), with first publication rights granted to the journal.

This is an open-access article distributed under the terms and conditions of the Creative Commons Attribution license (http://creativecommons.org/licenses/by/4.0/). 